Brit. J. industr. Med., 1953, 10, 32.

\title{
AN INVESTIGATION INTO THE REMOVAL OF RADIOACTIVE CONTAMINATION FROM THE HANDS*
}

\author{
BY \\ JAMES GREGORY \\ From the Ministry of Supply, Division of Atomic Energy (Production), Springfields Factory, Preston, Lancs.
}

(RECEIVED FOR PUBLICATION FEBRUARY 18, 1952)

The investigation was designed to determine the comparative value of certain washing agents in removing radioactive contamination from workers' hands, and was carried out at a production factory processing radioactive materials.

Where radioactive materials are handled cleanliness of the hands is of vital importance for the protection of the employee and for the manufacture of a product of extreme purity.

At this factory those working in contact with radioactive materials are provided with a complete change of clothing to be worn at all times in the factory and have to undergo a precise and definite washing procedure. When they actually enter an area where radioactive substances are encountered extra protective garments are provided. These consist of an overall of a boiler-suit type, a cap, rubber " surgeon's" boots, and plastic gloves. On leaving the area the gloves are washed and removed, after which the hands are scrubbed thoroughly with soap and water. The overall, cap, and boots are then removed and, before finally leaving the changeroom attached to the area, the hand washing is repeated, using a proprietary cleanser (cleanser $\mathbf{A}$ in the investigation).

On completing the day's work and before donning their own clothing, employees remove the special factory clothing and pass through a shower-bath. Their hands are checked on machines to determine their degree of radioactive contamination. This has come to be known as " hand-monitoring".

If hand-monitoring, which is carried out on an "alpha" hand-counting instrument (Type 1024), shows any contamination above a certain maximum permissible level the hands are washed again until the contamination has been removed. 1951.

* Shortened version of B.M.A. Occupational Health Prize Essay,
The provision of plastic gloves does not necessarily prevent contamination. Certain jobs must be done without gloves, especially where fine or delicate manual operations are involved, such as may occur with instrument, laboratory, or clerical work ; gloves may be discarded without permission or may have puncture holes or tears developed since the last inspection and test ; the inside of gloves may be contaminated after working with bare hands; or the hands may be contaminated by clothing after the gloves are removed.

Any radioactive contamination remaining on the hands is important for two reasons. There will be the local effect of radiation and the risk of conveying radioactive material to the mouth during eating, or, in some employees, from nail-biting.

Certain maximum permissible levels of hand contamination have been formulated, including that for alpha activity on the hands of 600 counts per minute per hand on the alpha hand-counting instrument.

For 10 months preceding October, 1950, a large number of hand-monitoring checks were carried out on employees at this factory, and $1.48 \%$ of the process workers showed some detectable radioactive contamination. The contamination was greater than 600 counts per minute per hand in only $0 \cdot 22 \%$.

Although this would appear to be reasonably satisfactory, there is no guarantee that it can be maintained without very close surveillance. The obvious aim, therefore, should be to attain $100 \%$ freedom from contamination of the hands before workers leave the factory.

The reasons why a few employees did not decontaminate their hands completely are either that the methods themselves are inadequate, or that employees do not use them in the correct manner.

At the same time, there remains some uncertainty 
that the best washing agents are being used. It was for this reason that this investigation was made.

A review of the literature shows that although there have been several studies of hand cleansing (Cruickshank, 1948; Forgie, 1946; Lane, 1949) it is only in the U.S.A. that tests on the removal of radioactive contaminants from the skin have been carried out (Mayer and Britton, 1948). These tests, however, were done with special isotonic solutions, incorporating detergents and germicides, on the shaven skin of rats and on dead human skin and are, therefore, not comparable with this series of tests with proprietary and other accepted washing agents on the human hand.

Further enquiries showed that no experiments on hand cleansing had been done in other similar factories but many suggestions as to the agents most suitable for removing radioactive contamination were received, and these substances were included in the tests.

The radioactive substances on the hands at the factory concerned may consist of one or more compounds. They may be bound down with grease or oil, or be physically trapped in coarse skin or under the nails. Removal, therefore, may prove difficult and the use of solvents or abrasives may result in dermatitis. Hence, a suitable washing agent, besides being efficient in removing contaminating materials, should also be safe and cause no complications after fairly frequent use. It should be pleasant to use and free from any objectionable characteristics, easily available, and not too costly.

\section{Experimental Methods}

In devising suitable experiments for comparing the efficiency of different washing agents, a contaminant comparable to the compounds likely to be met with in the factory and of known radioactivity was necessary. This contaminant could then be applied to the hands of volunteers and be removed by successive washes, ${ }^{*}$ the radioactivity remaining being measured after each wash by means of the alpha hand-monitoring machine.

The Alpha Hand-Monitoring Machine.-The alpha hand-monitoring machine used (Type 1024) is an air proportional type counter. It records the count of alpha-particles from each individual hand in terms of "tolerance" (T). ("Tolerance" is a maximum permissible count of 600 alpha counts per minute per hand.)

\footnotetext{
* None of the men reported any skin trouble from these repeated * None of the men reported any skin trouble from these repeated
washes, though two had some dryness and roughness of the hands, one after using titanium dioxide and the other following the washes one after using titan
}

The machines to be used are switched on some time before to warm up. When a reading is required " background " is first checked by means of a special switch. Having taken the background readings on the left and right hand sides, the hands are inserted and pressure by the finger tips activates the counters. The results are recorded only after a 15 -second counting period as shown on a timing dial on the machine.

The true counts are taken as the recorded handcount minus background for each hand.

In the following experiments all the results were first recorded in terms of tolerance and then converted to counts per minute for the purpose of tabulation and analysis.

The machines were periodically checked, frequently, though spasmodically, by an artificial hand bearing a contamination of $1 \times \mathrm{T}$ during the whole of the series of tests.

As the machine readings from 0 to several times tolerance are marked off on an approximately logarithmic scale, readings up to $1 \times$ tolerance (600 counts per minute) can be read off accurately to the nearest $0.1 \times \mathrm{T}$ (60 counts per minute), but above unity the scale becomes progressively smaller, until it is impossible to read it above $3 \times \mathrm{T}(1,800$ counts per minute). Therefore, any hand counts of over $3 \times$ tolerance were discarded. In addition, where a check hand count before contamination showed a count of more than tolerance on either hand, the man concerned was not used for that day's test.

Two machines were used to record the count remaining after each wash on each pair of hands, and, as the men were divided into two groups, a total of four machines was used throughout the tests. It was thus possible to compare each pair of machines for both left and right hands, and so obtain some evidence as to the accuracy of the machines.

From these results it was deduced that, for comparison of the results from the different washing tests, the average of the two readings obtained on either hand could be assumed to be an accurate count of the degree of contamination within the range $0-600$ counts per minute.

The Experimental Subjects.-The men chosen for the experiments, all of whom were volunteers, were drawn from the chemical laboratories attached to the factory. There would be only a small order of difference between the hands of scientific staff and process workers as both have to wash their hands frequently and to wear gloves.

Thirty persons were considered necessary for each 
of the tests carried out, but owing to leave and unrelated illness occasional substitution had to be made. A total of $\mathbf{4 7}$ men actually took part in the experiments and of these 28 were fairly regular attenders.

Nineteen tests were undertaken, only one test being carried out each day. Of the possible total of 570 there were actually 523 attendances $(91.8 \%)$, giving an average of 27.5 attendances per test, but of these 20 had to be discounted for reasons already mentioned, and in all 503 attendances (88.2\%) were analysed.

Six persons were tested at a time in two groups of three. This involved the use of two controllers, each with one pair of alpha hand-counting machines. Throughout the tests the controllers continually checked their methods to see that they were the same.

As the accuracy of the machines was unknown when the experiments were planned, it was considered desirable that the same men, so far as was possible, should come under the same controller using the same machines for each test. Then if machine errors or differences among the subjects were observed between the two sides the tests of each group could be compared separately. No selection as to this separation of the men into the two groups was made, however, and on the first day the first three men to arrive were sent to one side and the second three to the other side, and so on until all were divided. They were then asked to remain on the same side through the tests.

The following table shows how the men compared on the two sides :-

TABle A

COMPARISON OF SUBJECTS ATTENDING IN THE TWO GROUPS

\begin{tabular}{l|c|c}
\hline $\begin{array}{c}\text { Personnel Factor under } \\
\text { Comparison }\end{array}$ & $\begin{array}{c}\text { Controller A } \\
\text { (using Machines } \\
\text { I and II) }\end{array}$ & $\begin{array}{c}\text { Controller B } \\
\text { (using Machines } \\
\text { III and IV) }\end{array}$ \\
\hline $\begin{array}{l}\text { Number of regular attenders } \cdots \\
\text { Total attendance of "regulars " }\end{array}$ & 14 & 14 \\
Number of " reserves" & 220 & 214 \\
Total attendance of reserves $\cdots$ & 11 & 8 \\
\hline
\end{tabular}

On all but 17 occasions out of the total of 523 attendances $(3.25 \%)$ the men attended under the same controller at each visit.

The hands of all the men were measured and examined, and marked individual differences such as might introduce a difference between the groups were not found.

It was concluded that using these two groups as shown throughout the tests on their own sides, under the same controllers, and using the same pairs of machines, the results obtained from the different tests would be comparative in so far as any variable due to the subjects themselves was concerned.

Furthermore, in view of this conclusion and that relating to the accuracy of the machines, it was considered that the results from the two groups need not be analysed separately, but could be summated for each test and the mean count after each wash could be derived from the total personnel each day.

The Contaminants.-The radioactive substances chosen were radium residues and uranium peroxide $\left(\mathrm{UO}_{4}\right)$ and the bases used to hold these were vaseline (Paraff. Moll. Flav. B.P.) and talc (Cret. Gall. B.P.).

It was considered that any washing agent removing radioactive contamination in vaseline would also remove contamination mixed with industrial oil and grease, and that talc, with the addition of a little water and liquid paraffin for binding purposes, would prove similar to forms of industrial dirt as regards its holding power for any contamination.

After trials to determine the amounts required to give an approximate count of $10 \times \mathrm{T}$, when rubbed onto both hands, the following contaminants were made up :-

Radium Residues in Vaseline.-The first was $0.032 \mathrm{~g}$. of the sample of radium residues in $0.78 \mathrm{~g}$. vaseline. This was equal to $1 \mathrm{ml}$. by volume and was delivered onto the hands from a glass syringe, to give an approximate count of $10 \times \mathrm{T}$. This standard quantity was used to test the washing capabilities of all the washing agents chosen.

Uranium Peroxide $\left(\mathrm{UO}_{4}\right)$ in Talc.-The second was made up $2 \mathrm{~g}$. of $\mathrm{UO}_{4}$ in $1.9 \mathrm{~g}$. of talc made up into a paste with $3 \mathrm{ml}$. water and $1 \mathrm{ml}$. liquid paraffin. This was equal to a level teaspoonful, from which it was delivered onto the hands to give an approximate count of $10 \times \mathrm{T}$. It was used to test four selected washing agents.

Radium Residues in Talc.-The third was of $0.32 \mathrm{~g}$. of the sample of radium residues in $3.57 \mathrm{~g}$. talc made up into a paste with $3 \mathrm{ml}$. water and $1 \mathrm{ml}$. liquid paraffin. This was delivered onto the hands from a teaspoon to give an approximate count of $100 \times T$, and was used to test more rigorously the same four selected washing agents as above.

When applied, the contaminant was rubbed onto the hands for 60 seconds, the subjects being told to work it well into the skin, on the webs, and round the nails.

The Washing Agents.-The washing agents were chosen for a variety of reasons, some on the recommendation of outside authorities. The 11 chosen were as follows :- 
(1) White Windsor soap (called " hard soap" in this report to distinguish it from liquid soap), as already used in this factory; (2) liquid soap ; (3) cleanser A, a proprietary gel, as already in use at this factory and widely in industry, consisting of soap dissolved in petroleum ether with the addition of a small quantity of liquid germicide ; (4) " woodflour," a proprietary mixture of $50 \%$ soap powder and $50 \%$ woodflour, which Cruickshank (1948) considered to be most valuable in removing industrial mineral oil from workers' hands; (5) cleanser B, a proprietary gel including sulphonated castor oil with other adjuvants; (6) " neutral sulphonated castor oil", consisting of $98 \%$ of N.S.C.O. with $2 \%$ wetting agent, the mixture being diluted to 1 part in 5 of distilled water. This washing agent is recommended as an industrial hand cleanser in the oil dermatitis placards of the Ministry of Labour and National Service (Factory Department) ; (7) titanium dioxide, recommended by the United States Atomic Energy Commission (U.S.A.E.C.) and National Research Council, Canada (N.R.C. Canada) for the removal of radioactive contamination ; (8) cleanser $\mathrm{C}$, a proprietary cleansing paste recommended by the National Physical Laboratory, a slightly abrasive (siliceous) orthodox hand cleanser in a water base; (9) cleanser $\mathrm{D}$, a proprietary liquid detergent, also used by Cruickshank (1948) in his experiments, consisting of a solution of wetting agent and germicide in medicinal liquid paraffin; (10) cleanser $\mathrm{E}$, a sulphated secondary alcohol of the type $\mathrm{R}-\mathrm{CH}\left(\mathrm{O}-\mathrm{SO}_{3} \mathrm{Na}\right)-\mathrm{R}^{\prime}$ (where $\mathrm{R}$ and $\mathrm{R}^{\prime}$ range from C7 upwards) referred to by Forgie (1946) in an article on skin cleansing, and well known as an industrial wetting agent; (11) sodium citrate and potassium permanganate, also recommended by U.S.A.E.C. and N.R.C. Canada, for removal of Beta-gamma contamination.

The quantities of these 11 substances used in the experiments were the same in each case, so far as it was practicable to control this factor. The standard amount used was that which would be used by the average person if washing with that particular substance, as assessed by trial and error in the actual use of the material. Limitations as to the amount which could be used were obvious in some cases; for example, the quantity of a liquid agent which could be held in the hands without being spilled. Furthermore, the same amount of all similar cleansers was used: $4 \mathrm{ml}$. of the liquids were delivered onto the hands in two lots of $2 \mathrm{ml}$. each, the first delivery being gently rubbed in before the second one was given; powders were levelled off in small containers (approximately $5 \mathrm{ml}$. by volume) for dispensing ; and a level teaspoonful of the gels (approximately $6 \mathrm{ml}$.) was used.

Hard soap was the only difficult one to assess in this way, and a fixed time for lathering-up a damp scrubbing brush on a sizeable piece of soap was estimated.

All the agents were used in the manner recommended by the manufacturers or by other authorities and users.

In all cases tests were made to establish that the quantities delivered were consistent.

Timing.-It was estimated that half a minute per hand was a customary and suitable period for attention to each hand in normal washing. Accordingly, a fixed time-table was drawn up and the same methods and timings used for every wash.

Example: Cleanser B.-A given quantity of the cleansing agent was put on the dry hands of the person under test by the test controller, and this was worked well into the hands for 30 seconds.

The scrubbing brush was taken in the right hand and the bristles dipped into the water in the washbasin, which had been filled by the controller, then the left hand was scrubbed : palm, back, side, and thumb for 10 seconds, nails for 10 seconds, webs and sides of fingers for six seconds, junction of wrist and hands for four seconds. (The lapse of seconds and the parts to be scrubbed were called out by the controller.)

The brush was then taken into the left hand and again dipped into the water, and the scrubbing repeated on the right hand. The hands were next rinsed thoroughly in the basin of water for 15 seconds. Finally, the hands were dried on a clean towel.

Cross Contamination.-It was arranged that the persons under test used the same individual washbasin, scrubbing brush, and towel for each of their four washes.

Scrubbing brushes and towels were replaced with new and clean ones respectively for each person and for each test.

While the hands were being checked on the machines between washes the controller cleaned out and refilled the three wash-basins in use.

It was considered that these arrangements would eliminate any risk of cross-contamination between the subjects.

Any small degree of re-contamination of an individual's hands that might occur from the scrubbing brush and towel was not likely to be of any significance, and in any case would probably be no more than that likely to occur in the factory change-rooms. 
During analysis of the results it was found that there were only 11 occasions $(2 \cdot 1 \%)$ when recontamination might have occurred, as shown by a small increase in hand count after a third or fourth wash.

Water Temperature.-No standard temperature was laid down for the water in the wash-basins, but each controller endeavoured to ensure much the same degree and quantity of pleasantly hot water each time he filled the basins.

Consistency of the Routine.-In order to test the efficiency of the routine, Test No. 11 was a repetition of Test No. 1, using hard soap.

Except in the results after the first washes where the counts came outside the accepted accurate range of the machines, there was no significant difference between the counts recorded after the four washes with hard soap in these two tests (Table 1). on a special card used for all counts ; (b) contamination; (c) first wash ; (d) hands rechecked on the same two machines and results noted; (e) washings, followed by countings, repeated three times, or until both hands showed a reading of zero, i.e., instrument background count only.

Following the use of the first 10 washing agents against the radium residues in vaseline contaminant, hard soap was used again as a check.

Then the selected four agents were used on the $\mathrm{UO}_{4}$ and radium residues in talc contaminants.

Finally, a special test with nine men was undertaken with the eleventh agent (sodium citrate and potassium permanganate) against radium residues in vaseline as the contaminant. This method was considered industrially impracticable because of the quantities required, and the time taken for use. It could not be introduced in a comparable manner

TABLE 1

ANALYSIS OF HAND WASHES BY THE COUNT REMAINING AFTER EACH WASH

\begin{tabular}{|c|c|c|c|c|c|c|}
\hline \multirow{2}{*}{$\begin{array}{l}\text { Test } \\
\text { No. }\end{array}$} & \multirow[t]{2}{*}{ Washing Agent } & \multirow{2}{*}{$\begin{array}{l}\text { No. of Hands } \\
\text { Tested }\end{array}$} & \multicolumn{4}{|c|}{$\begin{array}{l}\text { Mean Readings per Hand after Successive Washes } \\
\text { (in counts/minute) }\end{array}$} \\
\hline & & & Wash 1 & Wash 2 & Wash 3 & Wash 4 \\
\hline $\begin{array}{r}1 \\
2 \\
3 \\
4 \\
5 \\
6 \\
7 \\
8 \\
9 \\
10 \\
11\end{array}$ & $\begin{array}{l}\text { Contaminant : Radium residues in } \\
\text { Hard soap } \\
\text { Cleanser D } \\
\text { Woodflour } \\
\text { Cleanser B } \\
\text { Liquid soap } \\
\text { Titanium dioxide } \\
\text { Neutral sulphonated castor oil } \\
\text { Cleanser C } \\
\text { Cleanser E } \\
\text { Cleanser A } \\
\text { Hard soap }\end{array}$ & $\begin{array}{l}\text { aseline (approxi } \\
60 \\
60 \\
54 \\
54 \\
54 \\
48 \\
56 \\
48 \\
52 \\
52 \\
54\end{array}$ & 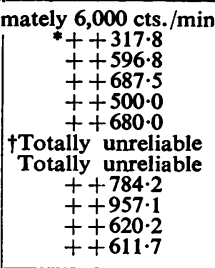 & $\begin{array}{r}\text { hand) } \\
126 \cdot 8 \\
203 \cdot 3 \\
214 \cdot 4 \\
172 \cdot 8 \\
191 \cdot 3 \\
++683 \cdot 2 \\
++651 \cdot 5 \\
281 \cdot 3 \\
++362.9 \\
195 \cdot 8 \\
169 \cdot 6\end{array}$ & $\begin{array}{r}64.8 \\
113.8 \\
125.9 \\
110.0 \\
113.6 \\
++404.9 \\
++373.7 \\
175.9 \\
229.1 \\
118.9 \\
78.9\end{array}$ & $\begin{array}{r}28.1 \\
73.0 \\
88.9 \\
73.0 \\
57.0 \\
272.5 \\
271.3 \\
97 \cdot 2 \\
147.7 \\
62.9 \\
33.1\end{array}$ \\
\hline 1 and 11 & Hard soap & 114 & ++457.0 & $147 \cdot 1$ & $71 \cdot 4$ & 30.4 \\
\hline
\end{tabular}

†Totally unreliable signifies that many of these results were so high as to give unreliable readings on the machine scale. *Numbers marked ++ include counts of 600 or more, and are, therefore, less reliable than the other results given.

This suggests that the routine of the tests was consistent.

\section{Procedure}

The men attended each morning for the tests. A different washing agent and/or contaminant was used each day.

The men attended in groups of six, spaced out evenly throughout the morning, and three men came under the supervision of each controller.

Each day's test was carried out in the following order :- (a) Hands checked in turn on two alpha hand-monitoring machines and results entered up amongst the other tests. (A special Appendix on this test is added at the end of this paper.)

\section{Experimental Results and Discussion}

The washing agents used in the tests were compared in two ways : (1) According to the count remaining after each wash; (2) by the number of hands cleared of contamination by each wash.

Results Analysed by the Count Remaining after Each Wash.-The results obtained in the washing tests were summated for each combination of contaminant and washing agent, and the mean count

TABLE B

RESULTS WITH RADIUM RESIDUES IN VASELINE AS CONTAMINANT

\begin{tabular}{|c|c|c|c|c|c|c|c|c|c|c|}
\hline $\begin{array}{c}\text { Washing } \\
\text { Agent }\end{array}$ & $\begin{array}{l}\text { Hard } \\
\text { Soap }\end{array}$ & $\begin{array}{l}\text { Liquid } \\
\text { Soap }\end{array}$ & $\underset{\mathbf{A}}{\text { Cleanser }}$ & $\underset{\text { B }}{\text { Cleanser }}$ & $\underset{\mathrm{D}}{\text { Cleanser }}$ & $\begin{array}{l}\text { Wood- } \\
\text { flour }\end{array}$ & $\underset{\mathbf{C}}{\text { Cleanser }}$ & $\underset{E}{\text { Cleanser }}$ & N.S.C.O. & $\underset{\text { Dioxide }}{\text { Titanium }}$ \\
\hline $\begin{array}{rr}\text { Hand count } & \text { after } \\
\text { Wash } 4 & . . \\
\end{array}$ & $30 \cdot 4$ & $57 \cdot 0$ & 62.9 & $73 \cdot 0$ & $73 \cdot 0$ & 88.9 & $97 \cdot 2$ & $147 \cdot 7$ & $271 \cdot 3$ & 272.5 \\
\hline
\end{tabular}


TABLE 2

COMPARISON OF WASHING AGENTS BY PERCENTAGE OF RADIOACTIVE MATERIAL REMOVED BY WASHES

\begin{tabular}{|c|c|c|c|c|c|c|}
\hline $\begin{array}{l}\text { Test } \\
\text { No. }\end{array}$ & Washing Agent & $\begin{array}{c}\text { No. of Hands } \\
\text { Tested }\end{array}$ & $\begin{array}{c}\text { Percentage } \\
\text { of Original } \\
\text { Count Removed } \\
\text { by First } \\
\text { Two Washes }\end{array}$ & $\begin{array}{l}\text { Percentage } \\
\text { of Count } \\
\text { Remaining } \\
\text { Removed by } \\
\text { Wash } 3\end{array}$ & $\begin{array}{c}\text { Percentage } \\
\text { of Count } \\
\text { Remaining } \\
\text { Removed by } \\
\text { Wash } 4\end{array}$ & $\begin{array}{c}\text { Percentage } \\
\text { of Original } \\
\text { Count Removed } \\
\text { by All } \\
\text { Four Washes }\end{array}$ \\
\hline $\begin{array}{r}1 \\
2 \\
3 \\
4 \\
5 \\
6 \\
7 \\
8 \\
9 \\
10 \\
11\end{array}$ & $\begin{array}{l}\text { Contaminant : Radium residues in } \\
\text { Hard soap } \\
\text { Cleanser D } \\
\text { Woodflour } \\
\text { Cleanser B } \\
\text { Liquid soap } \\
\text { Titanium dioxide } \\
\text { Neutral sulphonated castor oil } \\
\text { Cleanser C } \\
\text { Cleanser E } \\
\text { Cleanser A } \\
\text { Hard soap }\end{array}$ & $\begin{array}{c}\text { aseline (approxin } \\
60 \\
60 \\
54 \\
54 \\
54 \\
48 \\
56 \\
48 \\
52 \\
52 \\
54\end{array}$ & $\begin{array}{c}\text { tely } 6,000 \text { cts. } / \mathrm{min} \\
97 \cdot 9 \\
96 \cdot 1 \\
96 \cdot 4 \\
97 \cdot 1 \\
96 \cdot 8 \\
\overline{-} \\
95 \cdot 3 \\
\overline{96 \cdot 7} \\
97 \cdot 2\end{array}$ & $\begin{array}{l}\text { hand) } \\
48 \cdot 9 \\
44 \cdot 0 \\
41 \cdot 3 \\
36 \cdot 3 \\
40 \cdot 6 \\
- \\
37 \cdot 5 \\
39 \cdot 3 \\
53 \cdot 5\end{array}$ & $\begin{array}{c}56 \cdot 6 \\
35 \cdot 9 \\
29 \cdot 4 \\
33 \cdot 6 \\
49 \cdot 6 \\
- \\
\overline{4} \cdot \overline{7} \\
35 \cdot 7 \\
47 \cdot 1 \\
58 \cdot 0\end{array}$ & $\begin{array}{l}99.5 \\
98.8 \\
98.5 \\
98.8 \\
99.1 \\
95.5 \\
95.5 \\
98.3 \\
97.5 \\
99.0 \\
99.4\end{array}$ \\
\hline 1 and 11 & Hard soap & 114 & $97 \cdot 6$ & $51 \cdot 5$ & $57 \cdot 4$ & $99 \cdot 5$ \\
\hline
\end{tabular}

(per hand) remaining after each wash was calculated.

Table 1 shows these results in full for the first 11 washing tests. The summary Table $B$ shows the results after the fourth wash only, an average of the two tests with hard soap being given.

Table 1 also demonstrates the quick dramatic reduction in count with the first wash. This is presumably due mainly to the physical agencies of scrubbing and water. These common factors in all the first washes are apparent to a much smaller degree in successive washes, when the properties of the washing agent become the main factor in removing the contamination. Thus it is in the second, third, and fourth washes that the truly comparative values of the washing agents are to be assessed.

Further examination of Table 1 appears to indicate that, where the counts are within the assumed accurate range of the machines, successive washings produce an exponential fall in the counting rate as one would expect. Hence the efficiency of a cleanser can be expressed by the percentage of radioactive material removed by a standard wash, and this is shown in Table 2.
From this it would then appear that the washing agents can be grouped into three categories according to their efficiency :-

\begin{tabular}{|c|c|c|}
\hline Group (1) & High efficiency .. & Hard soap \\
\hline Group (2) & Medium efficiency & $\begin{array}{l}\text { Liquid soap } \\
\text { Cleanser B } \\
\text { Cleanser A } \\
\text { Cleanser D } \\
\text { Woodfour } \\
\text { Cleanser C }\end{array}$ \\
\hline Group (3) & Poor efficiency & $\begin{array}{l}\text { Cleanser E } \\
\text { Neutral sulphonated castor oil } \\
\text { Titanium dioxide }\end{array}$ \\
\hline
\end{tabular}

Further analysis by calculation of the standard deviation of the means, and using these figures to compare the significance of the results shown in Table 1, confirms this grouping. Each group is statistically significantly better than the next in order of efficiency.

From these results, the following were selected for the remaining tests :- Hard soap, apparently the best washing agent; cleanser $B$, a gel in the group of second-best agents ; woodflour, also in the group of second-best agents, and a powder found to be the best washing agent in Cruickshank's (1948) work on the removal of mineral oils from the skin ;

TABLE 3

ANALYSIS OF HAND WASHES BY THE COUNT REMAINING AFTER EACH WASH

\begin{tabular}{|c|c|c|c|c|c|c|}
\hline \multirow{2}{*}{$\begin{array}{l}\text { Test } \\
\text { No. }\end{array}$} & \multirow{2}{*}{ Washing Agent } & \multirow{2}{*}{$\begin{array}{l}\text { No. of Hands } \\
\text { Tested }\end{array}$} & \multicolumn{4}{|c|}{$\begin{array}{l}\text { Mean Readings per Hand after Successive Washes } \\
\text { (in cts./min.) }\end{array}$} \\
\hline & & & Wash 1 & Wash 2 & Wash 3 & Wash 4 \\
\hline $\begin{array}{l}12 \\
13 \\
14 \\
15\end{array}$ & $\begin{array}{c}\text { Contaminant : Radium residues } \\
\text { Cleanser E } \\
\text { Hard soap } \\
\text { Cleanser B } \\
\text { Woodflour }\end{array}$ & $\begin{array}{c}\text { in talc, giving co } \\
50 \\
54 \\
50 \\
58\end{array}$ & $\begin{array}{l}\text { tamination of approxi } \\
\text { †Totally unreliable } \\
\text { Totally unreliable } \\
\text { Totally unreliable } \\
\text { Totally unreliable }\end{array}$ & $\begin{array}{l}\text { ately } 60,000 \mathrm{cts} \\
*+1,154 \cdot 7 \\
++1,034 \cdot 9 \\
++752 \cdot 4 \\
++633 \cdot 1\end{array}$ & $\begin{array}{l}\text { hand } \\
++634.8 \\
++585.0 \\
++479.4 \\
354.9\end{array}$ & $\begin{array}{l}451 \cdot 2 \\
398 \cdot 4 \\
339 \cdot 0 \\
238 \cdot 5\end{array}$ \\
\hline $\begin{array}{l}16 \\
17 \\
18 \\
19\end{array}$ & $\begin{array}{c}\text { Contaminant: } \mathrm{UO}_{4} \text { in talc givin } \\
\text { Cleanser E } \\
\text { Hard soap } \\
\text { Cleanser B } \\
\text { Woodflour }\end{array}$ & $\begin{array}{c}\text { g contamination } \\
58 \\
48 \\
48 \\
48\end{array}$ & $\begin{array}{c}\text { approximately } 6,000 \\
++566 \cdot 9 \\
337 \cdot 6 \\
++827 \cdot 5 \\
316 \cdot 6\end{array}$ & $\begin{array}{r}\text { ts. } \text { min./hand } \\
192.6 \\
88.2 \\
220.0 \\
67.5\end{array}$ & $\begin{array}{r}85 \cdot 6 \\
53 \cdot 8 \\
110 \cdot 0 \\
25 \cdot 6\end{array}$ & $\begin{array}{r}39 \cdot 0 \\
21 \cdot 9 \\
51 \cdot 9 \\
5 \cdot 0\end{array}$ \\
\hline
\end{tabular}

†Totally unreliable signifies that many of these results were so high as to give unreliable readings on the machine scale. ${ }^{*}$ Numbers marked ++ include counts of 600 or more, and are, therefore, less reliable than the other results given. 
TABLE C

MEAN COUNT PER HAND (IN COUNTS PER MINUTE) REMAINING AFTER WASH 4

\begin{tabular}{|c|c|c|c|c|c|c|c|c|}
\hline Contaminant & \multicolumn{4}{|c|}{ Radium Residues in Talc } & \multicolumn{4}{|c|}{$\mathrm{UO}_{4}$ in Talc } \\
\hline Washing Agent & Woodflour & Cleanser B & Hard Soap & Cleanser E & Woodflour & Hard Soap & Cleanser E & Cleanser B \\
\hline Hand count after Wash $4 \ldots$ & $238 \cdot 5$ & $339 \cdot 0$ & 398.4 & $451 \cdot 2$ & $5 \cdot 0$ & 21.9 & $39 \cdot 0$ & 51.9 \\
\hline
\end{tabular}

cleanser E, a liquid cleanser, not in the best groups, and largely tested as a control agent.

Table 3 shows the results obtained using these agents against two contaminants, $\mathrm{UO}_{4}$ in talc and radium residues in talc. Although the large contaminating dose of the latter made it not possible to obtain reliable figures for all but a few of the washes, the results are still of value.

Table C, a summary of Table 3 , shows these results after the fourth wash only.

Table 4 shows the percentage of radioactive material removed by a standard wash against these two contaminants and the washing agents can again be grouped by their efficiency, the grouping being confirmed by the statistical significance.

Most of the results fall outside the assumed accurate range of the machines, but they suggest :Radium Residues in Talc

$\begin{array}{llllll}\text { Group (1) High efficiency } & \text {. } & \text {. } & \text { Woodflour }\end{array}$

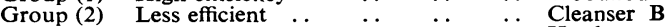

Hard soap

The results for $\mathrm{UO}_{4}$ in talc gave a somewhat different picture.

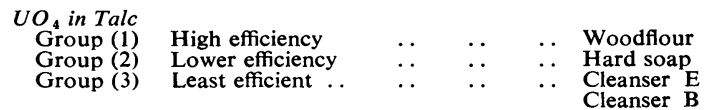

Results Analysed by Number of Hands Cleared after Each Wash.-Table 5 shows the number of hands "cleared" after each wash, clearance being accepted when the true count on the hand was nil.

Again the results show a possible method of grouping the washing agents by their efficiency.

Other factors to be taken into account in assessing these cleansing agents are the possible harm to the user ; simplicity as regards use and dispensing ; economy; and psychology, based on its ability to lather well and its attractiveness. Hard soap, liquid soap, and woodflour would appear to show up well under such an assessment.

TABLE 5

PERCENTAGE NUMBER OF HANDS CLEARED* AFTER THE VARIOUS WASHES

\begin{tabular}{|c|c|c|c|c|c|c|c|}
\hline \multirow{2}{*}{\multicolumn{2}{|c|}{ Washing Agent }} & & \multirow{2}{*}{$\begin{array}{l}\text { No. of } \\
\text { Hands } \\
\text { Tested }\end{array}$} & \multicolumn{4}{|c|}{$\begin{array}{l}\text { Percentage No. of Hands } \\
\text { Cleared after Successive } \\
\text { Washes }\end{array}$} \\
\hline & & & & $\underset{1}{\text { Wash }}$ & $\underset{2}{\text { Wash }}$ & Wash & Wash \\
\hline \multicolumn{8}{|c|}{$\begin{array}{c}\text { Contaminant : Radium } \\
6,000 \mathrm{cts} \cdot \mathrm{min} . / \text { hand })\end{array}$} \\
\hline Hard soap & & .. & 114 & 0.9 & $6 \cdot 1$ & $26 \cdot 3$ & $56 \cdot 1$ \\
\hline Cleanser D & .. & . & 60 & - & - & $6 \cdot 7$ & 20.0 \\
\hline Woodflour & .. & . & 54 & - & $1 \cdot 9$ & $5 \cdot 6$ & $16 \cdot 7$ \\
\hline Cleanser B & .. & . & $\begin{array}{l}54 \\
54\end{array}$ & $=$ & $=$ & $\begin{array}{r}7.4 \\
13.0\end{array}$ & $\begin{array}{l}25 \cdot 9 \\
44 \cdot 4\end{array}$ \\
\hline $\begin{array}{l}\text { Liquid soap } \\
\text { Titanium dioxi }\end{array}$ & de $\quad \ldots$ & & 48 & 二 & - & - & $2 \cdot 1$ \\
\hline Neutral sulpho & nated cas & or oil & 56 & - & - & - & 1.8 \\
\hline Cleanser C. &.$\quad \ldots$ & .. & 48 & - & - & - & $4 \cdot 2$ \\
\hline Cleanser E & . & $\because$ & $\begin{array}{l}52 \\
52\end{array}$ & $\bar{z}$ & 二 & $\overline{3 \cdot 8}$ & $\begin{array}{r}7 \cdot 7 \\
19 \cdot 2\end{array}$ \\
\hline Cleanser A & & & & & & & \\
\hline
\end{tabular}

Contaminant: Radium residues in talc (approximately 60,000

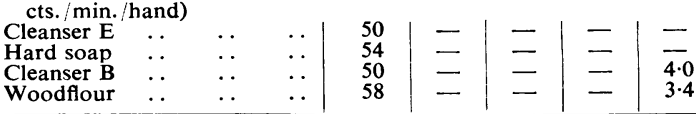

Contaminant : $\mathrm{UO}_{4}$ in talc (approximately $6,000 \mathrm{cts} . / \mathrm{min}$. /hand

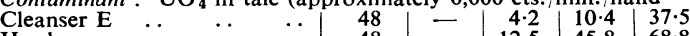
\begin{tabular}{rlll|l|l|r|r|r|} 
Cleanser E &. & $\ldots$ & $\ldots$ & 48 & Z & $4 \cdot 2$ & $10 \cdot 4$ & $37 \cdot 5$ \\
Hard soap & $\ldots$ & $\ldots$ & $\ldots$ & 48 & Z & $12 \cdot 5$ & $45 \cdot 8$ & $68 \cdot 8$ \\
Cleanser B & $\ldots$ &. &. & 48 & - & - & $8 \cdot 3$ & $29 \cdot 2$
\end{tabular}

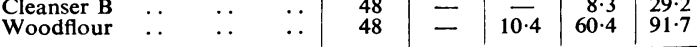

* Clearance was accepted when the true count on the hand was nil (i.e. the recorded hand count was the same as the machine background).

TABLE 4

COMPARISON OF WASHING AGENTS BY PERCENTAGE OF RADIOACTIVE MATERIAL REMOVED BY WASHES

\begin{tabular}{|c|c|c|c|c|c|c|}
\hline $\begin{array}{l}\text { Test } \\
\text { No. }\end{array}$ & Washing Agent & $\begin{array}{l}\text { No. of Hands } \\
\text { Tested }\end{array}$ & $\begin{array}{c}\text { Percentage } \\
\text { of Original } \\
\text { Count Removed } \\
\text { by First } \\
\text { Two Washes }\end{array}$ & $\begin{array}{l}\text { Percentage } \\
\text { of Count } \\
\text { Remaining } \\
\text { Removed by } \\
\text { Wash } 3\end{array}$ & $\begin{array}{l}\text { Percentage } \\
\text { of Count } \\
\text { Remaining } \\
\text { Removed by } \\
\text { Wash } 4\end{array}$ & $\begin{array}{c}\text { Percentage } \\
\text { of Original } \\
\text { Count Removed } \\
\text { by All } \\
\text { Four Washes }\end{array}$ \\
\hline $\begin{array}{l}12 \\
13 \\
14 \\
15\end{array}$ & $\begin{array}{c}\text { Contaminant : Radium residues in } \\
\text { Cleanser } \mathbf{E} \\
\text { Hard soap } \\
\text { Cleanser } \mathbf{B} \\
\text { Woodflour }\end{array}$ & $\begin{array}{c}\text { alc giving contan } \\
50 \\
54 \\
50 \\
58\end{array}$ & $\begin{array}{c}\text { nation of approxin } \\
\text { 二 } \\
=\end{array}$ & $\begin{array}{c}60,000 \text { cts. } \\
\text { 二 } \\
\text { - }\end{array}$ & $\begin{array}{r}\text { hand } \\
\frac{7}{32 \cdot 8}\end{array}$ & $\begin{array}{l}99 \cdot 2 \\
99 \cdot 3 \\
99 \cdot 4 \\
99 \cdot 6\end{array}$ \\
\hline $\begin{array}{l}16 \\
17 \\
18 \\
19\end{array}$ & $\begin{array}{c}\text { Contaminant: } \mathrm{UO}_{4} \text { in talc giving } \\
\text { Cleanser E } \\
\text { Hard soap } \\
\text { Cleanser B } \\
\text { Woodflour }\end{array}$ & $\begin{array}{c}\text { ontamination of } \\
58 \\
48 \\
48 \\
48\end{array}$ & \begin{tabular}{|c|} 
approximately 6,0 \\
$96 \cdot 8$ \\
$98 \cdot 5$ \\
$96 \cdot 3$ \\
$98 \cdot 9$
\end{tabular} & $\begin{array}{l}\text { cts. } \min _{55.6} \text { hanc } \\
39 \cdot 0 \\
50 \cdot 0 \\
62 \cdot 1\end{array}$ & $\begin{array}{l}54.4 \\
59 \cdot 3 \\
52 \cdot 8 \\
80.5\end{array}$ & $\begin{array}{l}99 \cdot 4 \\
99.6 \\
99.1 \\
99.9\end{array}$ \\
\hline
\end{tabular}


TABLE D

GROUPING OF WASHING AGENTS BY PERCENTAGE OF HANDS CLEARED AFTER FOURTH WASH

\begin{tabular}{c|c|c}
\hline Group & Washing Agent & $\begin{array}{c}\text { Percentage of } \\
\text { Hands Cleared } \\
\text { after Wash 4 }\end{array}$ \\
\hline & $\begin{array}{c}\text { Contaminant : Radium residues in } \\
\text { vaseline } \\
\text { Hard soap }\end{array}$ & \\
(1) & Liquid soap & 56 \\
$(3)$ & Cleanser B & 44 \\
& Cleanser D & 26 \\
(4) & Cleanser A & 20 \\
& Woodflour & 19 \\
& Cleanser E & 8 \\
& Cleanser C & 4 \\
(1) & Nitanium dioxide & 2 \\
(2) & Contaminant : UO ${ }_{4}$ in Talc & 92 \\
(3) & Woodflour & 69 \\
& Hard soap & 37 \\
\hline
\end{tabular}

An insufficient number of hands was cleared in the tests using radium residues in talc as the contaminant for the results to be of value.

\section{Conclusions}

Under the reported conditions of test, hard (white Windsor) soap was the most effective agent for cleansing the hands from contamination with radium residues in a greasy base. Other agents of some value were liquid soap, cleanser B, cleanser A, cleanser $\mathrm{D}$, and woodflour.

Woodflour was the most effective of the four agents tested in removing dry contaminants made up in talc (with minimal oil- and water-binding substances).

Sodium citrate and potassium permanganate, although apparently of value as combined washing agents, were considered to be industrially impracticable except in special cases, but are worthy of further investigation in practice for special washes of hands showing persistent contamination.

Cruickshank (1948) has shown that woodflour is a valuable agent for removing mineral oil from the skin. In view of this, hard soap and woodflour would appear to be the two most effective washing agents for the factory change-rooms.

These tests were used with radium and uranium contamination. Different elements and compounds are likely to behave in different ways and so respond in different manners to the various washing agents.

It cannot be assumed that the results obtained in these experiments will apply equally to other radioactive elements, and the fission elements may respond quite differently.

\section{Summary}

A method is described of assessing the comparative value of certain washing agents in removing radioactive contamination from workers' hands. The method is based on the use of alpha handmonitoring machines to detect contamination before and after a number of washes.

Ten cleansing agents were compared, and of these white Windsor soap and a mixture of equal parts of soap-powder and woodflour were found to be the two most effective for cleansing the hands of contamination with substances containing uranium and radium.

I desire to thank Sir Christopher Hinton, Deputy Controller of Production (A.E.), and the Chief Medical Officer, Ministry of Supply, for permission to publish this paper ; also the Principal Medical Officer, Division of Atomic Energy (Production), and my colleagues at the factory for their advice and encouragement, the principals and staff of the Chemical Inspectorate and Safety Department at the Factory for their assistance, and the manufacturers of the various cleansing agents for the supply of samples.

\section{REFERENCES}

Cruickshank, C. N. D. (1948). British Journal of Industrial Medicine, $5,204$.

Forgie, A. D. (1946). Brit. J. phys. Med., 9, 76.

Lane, C. G. (1949). J. industr. Hvg., 31. 220.

Mayer, S. W., and Britton, J. B. (1948). Report of U.S. Naval Radiological Defence Laboratory, AD-118(c).

\section{A P P E N D I X A}

The Sodium Citrate-Potassium Permanganate Washing Agent

This washing agent could not be introduced amongst the other agents used on a comparative basis because of the large quantities of materials used, the long time required, and the difficulty in giving comparative timings for scrubbing, rinsing, etc.

A special test using nine persons was, therefore, made to give some assessment of the value of this washing method.

The contaminant used was radium residues in vaseline to give a contamination of approximately 6,000 counts per minute.

The washing method consisted of immersing the hands in a basin of $24 \%$ sodium citrate solution for two minutes, then rubbing a saturated solution of potassium permanganate into the hands for one minute. With the scrubbing brush moistened in sodium bisulphate solution, each hand was scrubbed in turn until all the permanganate stain was removed. Finally, the hands were rinsed and dried.

The results obtained are shown in the following table :- 


\begin{tabular}{c|c|c|c}
\hline $\begin{array}{c}\text { Wash } \\
\text { No. }\end{array}$ & $\begin{array}{c}\text { Mean Readings } \\
\text { per Hand }\end{array}$ & $\begin{array}{c}\text { No. of Hands } \\
\text { Cleared } \\
\text { (No. used =18) }\end{array}$ & $\begin{array}{c}\text { Percentage of } \\
\text { Hands Cleared }\end{array}$ \\
\hline 1 & 920 & - & $\overline{5.6}$ \\
2 & $\begin{array}{c}111.7 \\
41.7\end{array}$ & 5 & $\begin{array}{r}33.3 \\
5\end{array}$ \\
5.0 & 16 & 88.8 \\
\hline
\end{tabular}

This would appear to show that the method is of value, but its assessment by the factors used for the other agents immediately indicates how impracticable it would be as a method of washing in the change-rooms.
Assessed by the properties of simplicity, economy, and psychology, this washing agent compared unfavourably with the other agents used in the tests. In addition, large quantities of materials and containers are required, and detailed supervision would be necessary.

However, it might be of value as an additional washing method in resistant cases, but again, time is a limiting factor at the end of a worker's shift, and the above results do not indicate its true worth compared with the other tests. 